\title{
Early Pregnancy Diagnosis by the Ultrasonographical Device and Observation of Fetal Growth in Cynomolgus Monkeys (Macaca fascicularis)
}

\author{
Fumiaki CHO, Hayato NARITA*, Takahiro ONO* \\ and Shigeo HONJO \\ Tsukuba Primate Center for Medical Science, The National Institute \\ of Health, and *The Corporation for Production and Research \\ of Laboratory Primates, Hachimandai, Yatabe-machi, \\ Tsukuba-gun, Ibaragi-ken, 305, Japan.
}

(Received 10 June 1986/Accepted 1 October 1986)

\begin{abstract}
Usefulness of the ultrasongraphical device (USD) for early diagnosis of pregnancy and for observation of fetal growth was examined in the cynomolgus monkey (Macaca fascicularis). Firstly, 50 females, each of which was mated for 24 hours in an individual cage, were used. They were diagnosed for pregnancy by the use of USD 15 to 29 days and 35 days after mating. Then, 20 of them were judged to be pregnant. The early pregnancy diagnosis was based on the detection of gestational sac (GS) in the uterus. The GS was detected 20.0 1.8 days aftes mating. The duration from the day on which GS was first detected to the day on which the heart beat of embryo (HBE) was detected averaged $5.6 \pm 1.5$ days. In 17 of these 20 pregnancies, GS was detected 17 to 23 days after mating. As regards the remaining three pregnant cases, GS and HBE were simultaneously detected on the 28 th day of pregnancy in two cases, and on the 35 th day in one case. Secondly, 225 females who were mated by the routine 3 day-mating system were used. Pregnancy diagnosis by USD was conducted on the 21 st, 28 th and 35 th day after mating. Ninety-six of the 225 females were judged to be pregnant. In 33 (34.1\%) of the 96 pregnant cases, GS was detected on the 21 st day of pregnancy. In 57 females $(59.4 \%)$, GS was detected on the 28 th day of pregnancy, and in the remaining $6(6.2 \%)$ cases GS was detected on the 35 th day. Furthermore, it was able to judge conditions of fetal growth by measuring the size of GS and biparietal diameter. In conclusion, USD is a useful means for the early diagnosis of pregnancy and the observation of conditions of fetal growth in the cynomolgus monkey.
\end{abstract}

\section{超音波診断装置によるカニクイザルの \\ 早期妊娠診断之胎仔の発育観察}

\author{
長文昭・成田勇人*·小野孝浩*.木左重男 \\ 国立予研筑波医学実験用霹長類センター \\ *社団法人予防衛生協会
}

医療機器としての超音波診断装置（Ultrasonographical Device, USD) は, 近年長足の進歩・改良 
は動物の大きさ別にウシ，ウマから実験動物のウサギ， ラットに至る広い範囲に対応して多様な機種が開発され ている。これら USD をサル類に適用した 報告として は，既にアカゲザル（Macaca mulatta）の胎仔成長を 主題とした報告 $[5,6,7]$ がある。私どもはUSD が持つ 即時性, 無侵襲性等の特長に着目して,ここ $3 \cdot 4$ 年来 同装置を実験用サル類の大規模繁殖の場で利用してき た。私どものカニクイザル (Macaca fascicularis) 繁 殖技術への USD の利用は，他の技術的調査研究や改善 $[1,2]$ と相まって現場での作業に大きな革新をあたらし ている。本報はそれらのうちの早期妊娠診断と胎仔の発 育観察とに関するあのである。

\section{材料およぶ方法}

I . 動物と交配方式：被検雌カニクイザルは，筑波医 学実験用霊長類センター [4]の繁殖コロニーにおいて種 ザルとして使用している動物である。交配は，正常な長 さの月経周期を連続 2 回観察した後，3 回日の月経出血 の初日から数えて第11日に，雌ザルを雄ザルケージに入 れ，一定期間同居させることによった。妊娠日龄は同剭 初日を零日として算出した。USD 導入の当初には, ま ず，雌50頭をもちい，受胎期判定の䛊差が極力少なくな るよう同居時間を24時間にして交配した。次いで，日常
的交配方式にしたがい 3 日間交配された雌 225 頭（うち 後刻妊娠之判定されたもの96頭）を用いた。

II. 飼育条件：飼育室の照明は 14 時間の蛍光灯点灯 と，10牔間の消灯の繰返しである。空調条件としては， $100 \%$ の新鮮空気を 1 時間に 10 回換気し, $25 \pm 2{ }^{\circ} \mathrm{C}$ の温 度と $60 \pm 10 \%$ の湿度を保持した。飼料は，个前にリン ゴ,ミカン条 $100 \mathrm{~g}$ を給与し, 午後に 2 回に分けて計70 $\mathrm{g}$ の 固型飼料（オリエンタル酵母製 A S 型）をあたえ た。飲水は自動給水装置により自由に摄水させた。交配 時以外, 雌ザルは $45 \mathrm{~cm} \mathrm{~W} \times 60 \mathrm{~cm} \mathrm{D} \times 60 \mathrm{~cm} \mathrm{H}$ のステン レススチール製金網ケージに収容された。

III. USD による妊娠判定法, (1)装置：USD は Aloka 株式会社製，SSD-256（電子リニア型）である。用いた 探触子の周波数は $5 \mathrm{MHz}$ である。(2)判定：診断はケタ ラール50 (三共パークデイビス製) による麻酔下で実施 した。子宮内に胎のう（Gestational Sac, GS) が検出 された場合に「妊娠」之診断した。その後, GS 内に胎 芽を，さらに胎芽の中または辺縁に胎芽心拍を検出する ことにより妊娠を再確劷した。(3)診断スケジュール：24 時間交配後の50頭については，同居初日を零日とした第 15日より第29日までの每日と第35日に㟝断を試みた。日 常的な慗殖の作業である 3 日交配後の被検雌ザル 225 頭 については，第 $21 ， 28$ と 35 日に診断をおこなった。

IV. GS および胎仔の大きさの測定：「妅娠」と診断

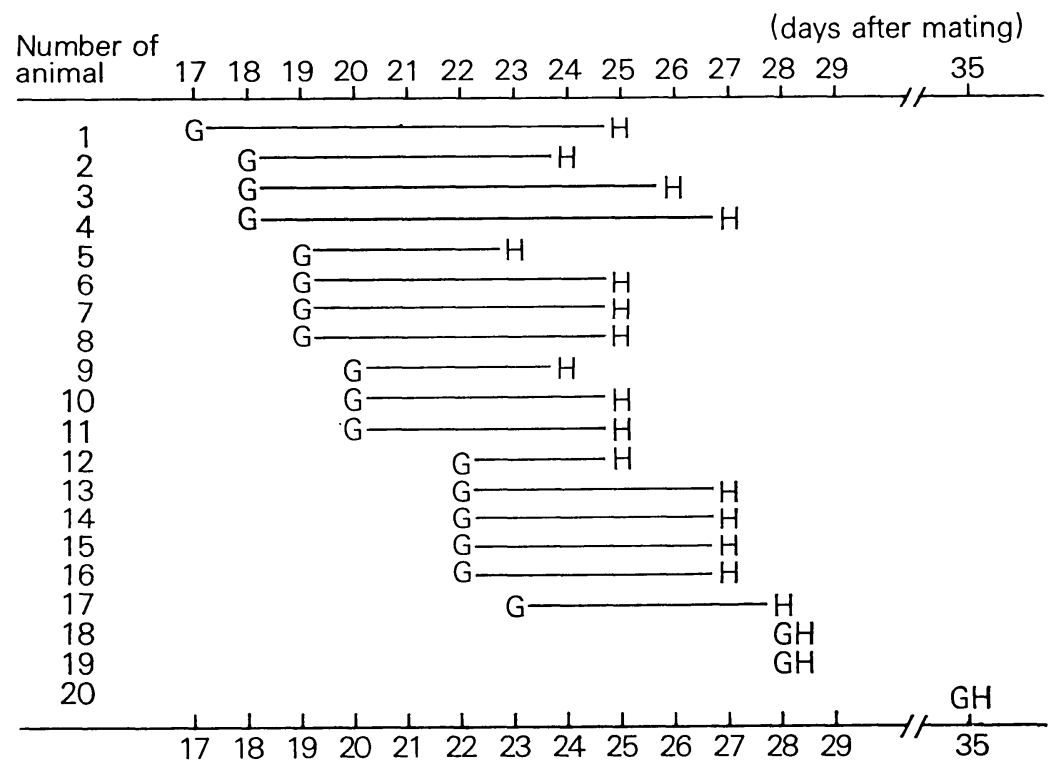

[Abbrev.] G: Detected gestational sac. H: Detected heart beat.

Fig. 1. The first day on which gestational sac and the heart beat of embryo were detected in the uterus by the USD after 24-hour-mating. 
された倜体では，その GS の大きさを長径と短径につい て $1 \sim 3$ 回（第 $21 ， 28$ 扰よび 35 日）計測した。さらに, 妊娠個体については, 妊娠 $8,12,16,20$ および 22 週 秢時に胎仔の頭部大横径 (Biparietal Diameter, BPD) を測定した。

成 績

24 時間交配で 50 例中 20 例が妊娠した。妊娠した 17 例

Table 1. Detection of the gestational sac and the heart beat of embryo by USD on different days after mating in 96 females who became pregnant after 3-day-mating.

\begin{tabular}{lcccc}
\hline $\begin{array}{l}\text { Number of days } \\
\text { after mating }\end{array}$ & & 21 & 28 & 35 \\
\hline Gestational sac & + & 33 & $90(57)$ & $96(6)$ \\
& - & 63 & 6 & 0 \\
\hline $\begin{array}{l}\text { Heart beat of } \\
\text { embryo }\end{array}$ & + & 0 & 70 & 96 \\
\end{tabular}

Number in parenthesis indicates number of pregnant females whose GS was first detected.

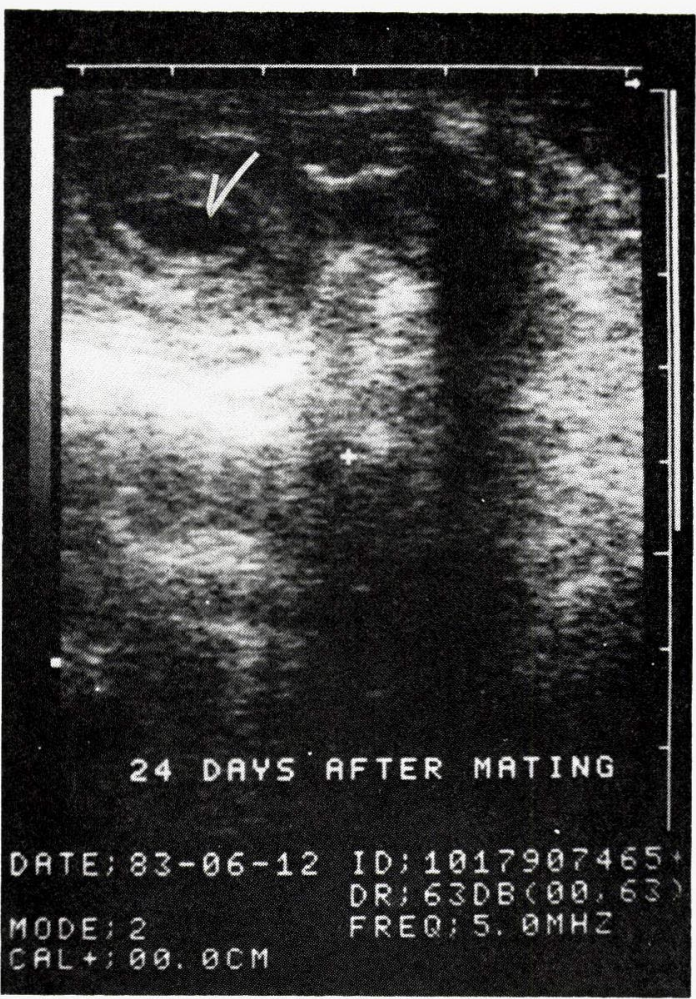

Fig. 2. An image of gestational sac detected on the 24th day of pregnancy.
は，胎榆第 17 日から第 23 日の間に妊娠と診断し得た (Fig. 1)。GS が見出された胎秢の平均は 20.0 日であっ た。胎芽心拍は，乙れより平均 5.6 日後れて 確認され た。なお残り 3 例のうち 2 例では第28日に，他の 1 例で は第 35 日に, GS，胎芽および胎芽心拍が同時に確認さ れた。

3 日間交配による妊娠数は96䫓であった (Table 1)。 これら96頭のうち, 胎齢第21日における診断では33頭, すなわち $34.4 \%$ 検出し得た。次いで第 28 日の診断で新

Table 2. The size of the gestational sac.

\begin{tabular}{llrl}
\hline \multicolumn{4}{c}{ Number of days after mating } \\
& \multicolumn{1}{c}{21} & 35 \\
\hline $\mathrm{Mj}$ & $8.2 \pm 3.1^{*}(33)^{* *}$ & $12.1 \pm 3.7(90)$ & $19.6 \pm 4.7(96)$ \\
$\mathrm{Mi}$ & $4.3 \pm 1.6(29)$ & $7.3 \pm 2.2(80)$ & $11.5 \pm 3.2(89)$ \\
\hline$*$ : Mean \pm S.D. \\
**: The values in parentheses are the number of \\
animals. \\
$\mathrm{Mj}:$ Major axial length \\
$\mathrm{Mi}:$ Minor axial length
\end{tabular}

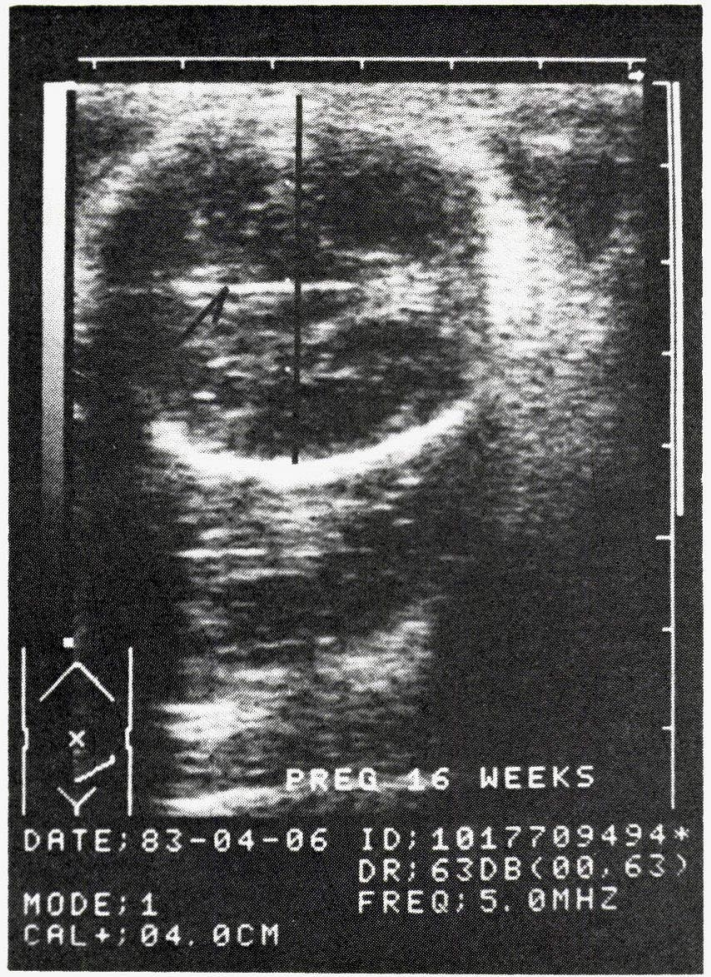

Fig. 3. An image of fetal head in 16 th week of gestation. An echo line (arrow) indicating fissura longitudinalis cerebri can be seen. 
Table 3. The fetal biparietal diameter with respect to gestational age.

\begin{tabular}{cccccc}
\hline \multirow{2}{*}{$\begin{array}{l}\text { Number of } \\
\text { animals used }\end{array}$} & \multicolumn{5}{c}{ Gestational age } \\
\cline { 2 - 6 } & 8 weeks & 12 weeks & 16 weeks & 20 weeks & 22 weks \\
\hline 96 & $13.4 \pm 1.7^{*}$ & $26.2 \pm 1.8$ & $36.3 \pm 1.7$ & $41.9 \pm 2.1$ & $42.8 \pm 2.4$ \\
\hline *: Mean \pm S.D. & & & & &
\end{tabular}

たに妊娠と判定されたものは 59.4\% (57/96) 同じく第 35 日の診断では $6.2 \%(6 / 96)$ であった。

胎のうの大きさの测定值は, Table 2 に示したとお りである。交配後第21日に検出された GS の長径は，平 均 $8.2 \pm 3.1 \mathrm{~mm}$, 短径は平均 $4.3 \pm 1.6 \mathrm{~mm}$ で, 柿の種 のような形であった (Fig. 2)。第28日のそれは, 12.1 $\pm 3.7 \mathrm{~mm} \times 7.3 \pm 2.2 \mathrm{~mm}$ ，第35日では $19.6 \pm 4.7 \mathrm{~mm} \times$ $11.5 \pm 3.2 \mathrm{~mm}$ と増大した。

妊娠 8 週齢における胎仔の BPD は平均 $13.4 \pm 1.7$ $\mathrm{mm}$, 妊娠 12 週龄の BPD は平均 $26.2 \pm 1.8 \mathrm{~mm}$, 妊娠 16 週粭の BPD は平均 $36.3 \pm 1.7 \mathrm{~mm}$, 妊娠 20 週齿の $\mathrm{BPD}$ は $41.9 \pm 2.1 \mathrm{~mm}$, そして妊娠 22 週龄の BPD は平 均 $42.8 \pm 2.4 \mathrm{~mm}$ であった (Table 3, Fig. 3 )。

\section{考察}

当センターにおけるカニクイザルの早期妊娠診断は通 常, 交配後 5 週目で子宮の膨らみを触知する，いわゆる 子宮触診法により実施してきた。この方法は多少の熟練 を要するとはいえ, 極めて簡便, 確実である。しかし, どんなに早くとも 4 〜 週後でないと判定できない。ま た, 血中胎盤絨毛性ゴナドロピン (CG/LH) を検出し, 妊否を診断するととあ可能である。この場合妊否の判定 には少なくとも, 数時間を要するが, 交配後 3 週(21日) で全妊娠例の $86 \%$ を検出できる $[8]$ 。

一方ここに報告したように，本装置により，ほとんど の妊娠例が胎齢17〜23日の間に妊娠と判定されたととか ら, カニクイザルの早期妊娠診断のための USD の有用 性は非常に高いあのと言える。なお，最も早期，つまり 第 17 日と第 19 日に GS を見出し得た例，および第 35 日 に GS と胎芽心拍とを初めて同時に見出し得た例の計 3 例は，それぞれ第50，45，53日に流産した。これらの流 産は月経様出血を観察した日に実施したUSD による観 察で GS の存在は明膫であるにもかかわらず，胚および 胎芽心拍は共に存在しないととが観察されたため流産と 判定されたものである。残る17例は正常仔を分婏した。

ところで, 今回 GS および胎芽心拍を初めて検出し得
た胎秢に関しては可成り大きな個体差 (GS : 第 17〜23 日，胎芽心拍：第23〜38日）が認められた。このような 個体差は, 今後 USD の解像力がさらに増強され, かつ また術者が一層観察に習熟するならば，次第に小さくな るあのと予想される。

交配後20日のアカゲザル (Macaca mulatta) の GS の大きさは $6 \pm 5 \mathrm{~mm}, 25$ 日では $13 \pm 5 \mathrm{~mm}, 30$ 日では $19 \pm 5 \mathrm{~mm}$ そして，35日では $26 \pm 5 \mathrm{~mm}$ であると報告[5] されている。第35日に拈いて，すでにカニクイザルとの 差が平均値で $7 \mathrm{~mm}$ ああるととは注目に值する。このア カゲザルの報告は胎芽心拍の観察には触れていない。ま た, Nyland らが用いた装置の探触子はセク夕型であっ たので胎仔の BPD をはじめとする胎仔の身体各部が計 測されている。一方，私どあの使用した装置はリニア型

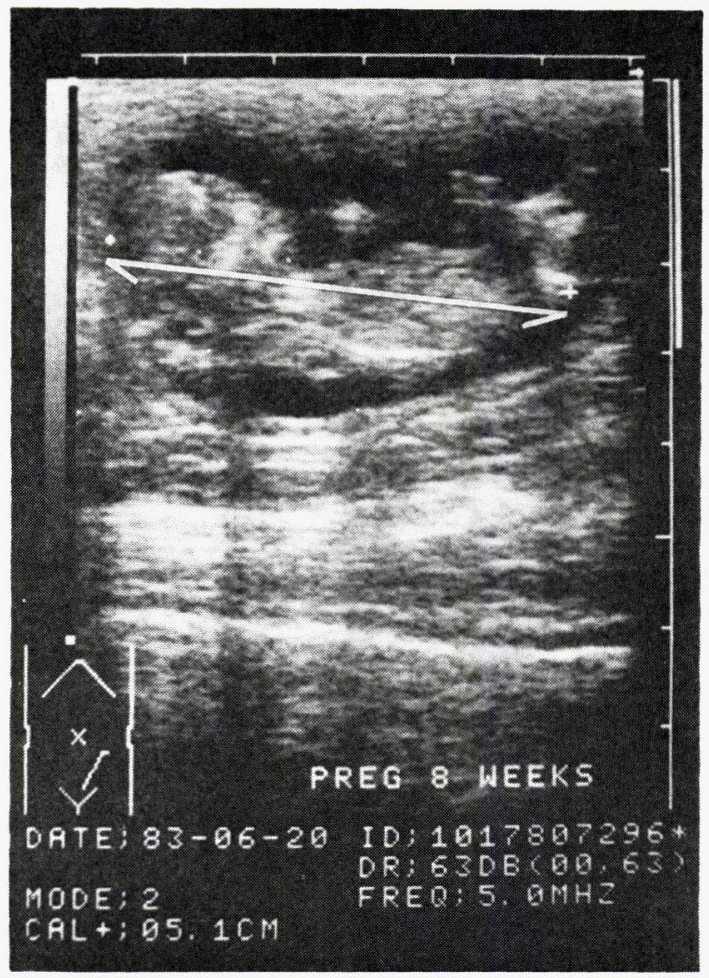

Fig. 4. An image of 8-week-old fetal crown-rump length (the arrow). 


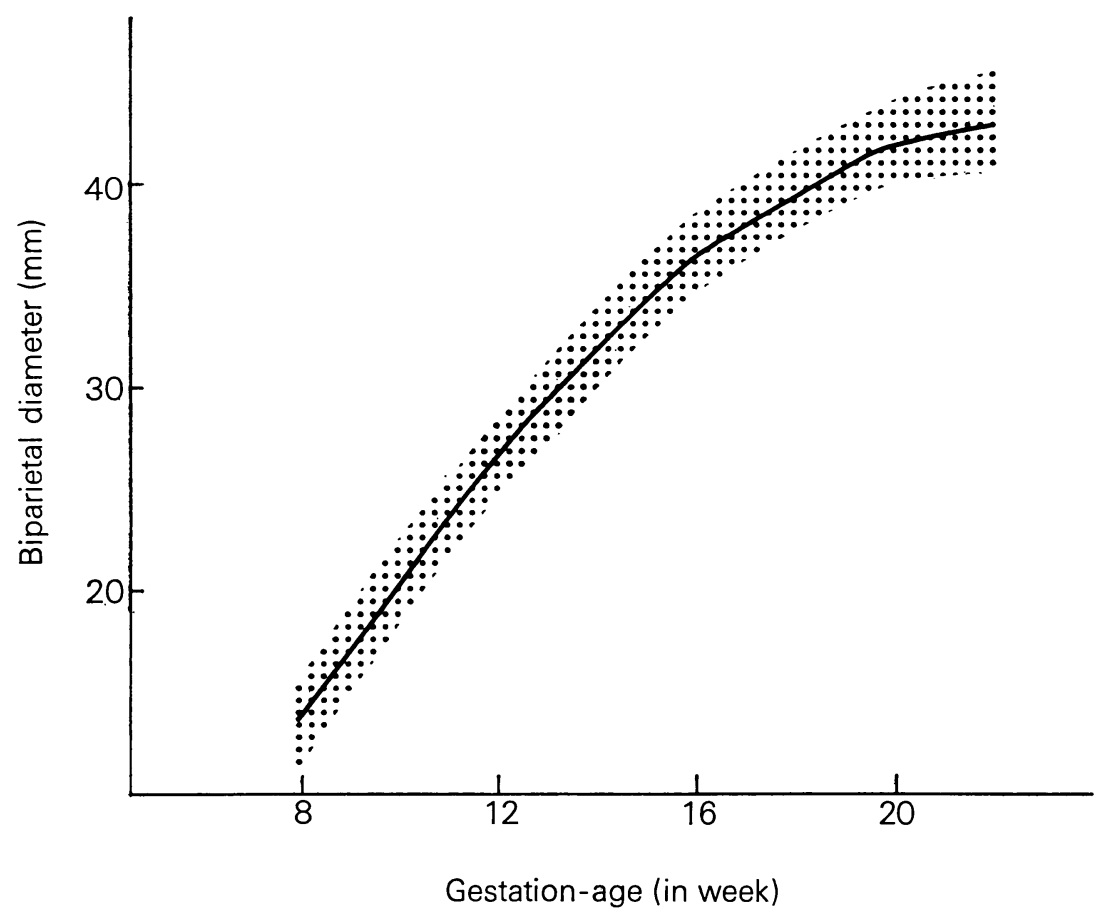

Fig. 5. Increase of the biparietal diameter with increasing gestation age.

であったために，最大限 8 週㱓までしか胎仔の頭臂長を 計測し得ず (Fig. 4), それ以上の胎秢の胎仔の全身を 一画面に映し出すことはできなかった。しかし，頭部全 体を映し出すととは可能であったので胎仔発育の指標之 して，胎仔の BPD を観察・計測することができた。 Fig. 5 に示した值は, 当センターのカニクイザル繁殖 コロニーの現場作業において既に活用されている。すな わち， $8,12,16,20$ と 22 週齢胎仔で $\mathrm{BPD}$ を計測し, その測定値を Fig. 5 の值と照合, 比較し胎仔が正常に 発育しているか否かを確認している。

GS や BPD の胎㱓に伴う増大に性差があるかか否か はひとつの問題である。とてろが私どあは未だ画面上で 性を判別するてとに成功していないので出生時に判明し た雌雄別にもとづいて Tables 2, 3 のデータを整理し, 性差の有無につき検討した。その結果は，妊娠のいずれ の時期においても雌雄間で有意差を検出し得なかった $(\mathrm{p}=0.05)$ 。なお，参考資料として Table 4 K，BPD の計測対象とした胎仔の雌雄別在胎期間 (=妊娠期間) と出生時体重を示した。これらの值は, いずれも既に私 どあのカニクイザル繁殖コロニーで標準值としているあ の [3]とほとんどおなじである。また雌より雄の出生時 体重が大きい。今後 USD による胎仔の身体各部の観察
・計測を進め, 雌雄の体重差をあたらしているあのが, 身体のどの部分であるかを検討して行きたい。なお操作 技術上の問題であるが GS を観察する時, 探触子と腹壁 面とのなす角度, 探触子が腹壁を圧定する強さ, 探触子 を動かす方向や速さ等を少しずつ変えて走査を繰返し, 画像の判断に䛊りのないように充分注意を払う必要があ る。すなわち, 角度を変えて像を確認し, 压定の強さを

Table 4. Gestation period and birth weight of the newborns who were measured for their biparietal diameters (presented in Table 3).

\begin{tabular}{lccc}
\hline Sex & $\begin{array}{l}\text { Numberof } \\
\text { animals } \\
\text { used }\end{array}$ & $\begin{array}{l}\text { Gestational** } \\
\text { period } \\
\text { (day) }\end{array}$ & $\begin{array}{l}\text { Birthe } \\
\text { weight*** } \\
(\mathrm{g})\end{array}$ \\
\hline Male & 45 & $164.7 \pm 5.5^{*}$ & $368.0 \pm 71.8$ \\
Female & 51 & $165.0 \pm 4.7$ & $345.0 \pm 61.8$ \\
Combined & 96 & $165.0 \pm 5.1$ & $355.8 \pm 67.6$ \\
\hline
\end{tabular}

$*$ : Mean \pm S.D.

** \& ***: Differences in the average values between male and female newborn were statistically examined at $5 \%$ level.

**: No significant difference was detected.

***: Statistically significant difference was detected $(p=0.037)$. 
極く僅かに変えても GS に極端な変形の無いことを確か めねばならない。

さらにまた，私どもが今回使用した装置の探触子の振 動数は $5 \mathrm{MHz}$ であったが, 今日では $7.5,10 \mathrm{MHz}$ の探 触子屯開発され，一部ではこれらが実用化されている。 最近私どもは $7.5 \mathrm{MHz}$ の探触子（メカニカル・セクタ 型）を試用する機会があったが，ここに報皆した成績よ りも若干早く妊娠晾断が 可能であるとの 絬果を得てい る。

\section{要 約}

超音波診断装置 (USD) を用いて，実験用カニクイザ ルの妊娠診断と, 妊娠個体に抢ける胎仔の発育観察を行 なった。妊娠の判定は同装置により映し出された子宮内 に胎のう（GS）を検出し得るか否かによった。まず当セ ンター繁殖コロニーの雌ザル50頭を, その交配適期に24 時間交配した。それらは交配日を零日と算えて第15～29 日までの間および第35日に診断し，うち20頭がこの間に 妊娠と判明した。これら20頭中17頭では第17～23日の間 に GS を検出することができた。GS 検出時の平均胎柃 は20.0日であった。GS 検出後平均 5.6 日で GS 内に胎 芽心拍が認められた。残りの 3 頭中 2 頭では第28日に, 他の 1 頭では第35日にいずれも，GS と胎芽心拍が同時 に検出された。次に, 日常的な繁殖方式である 3 日間交 配後の 225 頭を対象とし, 第 21,28 と 35 日の 3 回同装 置により妊娠診断を試み，96頭で妊娠が確認された。96 頭中33頭 (34.1\%) では第21日に，57頭 (59.4\%) では 第28日に，そして残り 6 頭 (6.2\%) では第35日にそれ ぞれ GS が検出された。次に本装置で GS の大きさ，お よび胎仔の頭部大横径 (BPD) を測定することにより胎 仔の発育の程度を判断することが，また，心拍動の有無 を観察することにより胎仔の生死を判定することが可能
であった。以上の結果から，USD はカニクイザルの早 期妊娠診断掞よび胎仔発育観察によって極めて有用であ ると判断される。

\section{文献}

[1] Cho, F., Hanari, K., Suzuki, M.T., and Honjo, S. (1985). Relationship between fetal position and stillbirth in the cynomolgus monkeys (Macaca fascicularis): Retrospective analysis. J. Med. Primatol., 14, 169-174.

[2] Cho, F., Suzuki, M., and Honjo, S. (1986). Adoption success under single-cage conditions by cynomolgus macaque mothers (Macaca fascicularis). Am. J. Primatol. 10, 119-124.

[ 3 ] Honjo, S., Cho, F., and Terao, K. (1984). Establishing the cynomolgus monkey as a laboratory animal. In "Research on Nonhuman Primates" (ed. by A.G. Hendrickx) Advances in Veterinary Science and Comparative Medicine., 28, 51-80. Acad. Press, N.Y.

[4] Honjo, S. (1985). The Tsukuba Primate Center for Medical (TPC): An outline. J. Med. Primatol., 14, 75-89.

[5] Nyland, T. G., Hill, D. E., Hendrrickx, A. G., Farver, T. B., McGahan, J. P., Henrickson, R., Anderson, J., and Phillips, H.E. (1985). Ultrasonic assessment of fetal growth in the nonhuman primate (Macaca mulatta). J. Clin. Ultrasound., 12, 387-395.

[6] Peterson, E. N., Hutchinson, D. L., Sabbagha, R.E, Royal, J.S., and Levitt, M.J. (1972). Sonography and amniocentesis as predictors of gestational age and fetal growth in the rhesus monkey. Am. J. Obstet. Gynecol., 114, 883-889.

[7] Sabbagha, R.E., Turner, J. H., and Chez, R. H. (1975). Sonar biparietal diameter growth standards in the rhesus monkey. Am. J. Obstet. Gynecol., 121, 371-374.

[8] Yoshida, T., Suzuki, K., Cho, F. and Honjo, S. (1987). Serum chorionic gonadotropin levels determined by radioreceptorassay and early diagnosis of pregnancy in the cynomolgus monkey (Macaca fascicularis). Am. J. Primatol., 12, 101 $-106$. 